\title{
ASYMMETRY IN PRICE TRANSMISSION MECHANISM: THE CASE OF SLOVAK POTATO MARKET
}

\author{
Miroslava Rajcaniova* ${ }^{1}$, Jan Pokrivcak ${ }^{1}$
}

\begin{abstract}
Address: Miroslava Rajcaniova,
${ }^{1}$ Slovak University of Agriculture, Faculty of Economics and Management, Department of Economics, A.Hlinku 2, 94976 Nitra, Slovakia, phone: 00421-37-6414-586

*Corresponding author: miroslava.rajcaniova@uniag.sk
\end{abstract}

\begin{abstract}
This paper examines price transmission mechanism between farm and retail levels in vertical chain of potatoes. Time series analysis starting with cointegration approach is used to study price linkages between producer and consumer prices in potato market in Slovakia. We test for an existence of structural break in time series data (Gregory - Hansen test) in the observed period and allow for an existence of non-linear relationship between prices at various levels of vertical chain by using threshold autoregressive models. We found an evidence of structural break and existence of asymmetry in price transmission along the potato supply chain.
\end{abstract}

Keywords: price, asymmetry, transmission, cointegration, potatoes

JEL: Q11, Q13, Q18

\section{INTRODUCTION}

Price transmission from producer to consumer prices is a key characteristic of the supply chain and has received a lot of attention in the literature. There was a significant effort devoted in the empirical literature to quantify of magnitude, speed, and nature of price transmission from producer to consumer prices. Vertical price transmission may be imperfect if price changes at one level are not fully transmitted to another level; if there is a time lag between price adjustments at different levels or if there is an asymmetry in reaction between positive and negative price shocks (Bunte 2006). In agricultural markets we often observe that an increase of producer prices is transmitted more fully and faster to consumer prices while producer price decrease is passed-through the supply chain to consumer prices incompletely and at a lower speed (Vavra and Goodwin 2005). Empirical studies show that asymmetric price transmission is a rule rather than exception (Peltzman 2000).

In the food supply chain, asymmetric adjustment to price shocks can be observed due to the existence of adjustment costs, menu costs and information asymmetries (Ball and Mankiw 1994), inventory behaviour of retailers (Balke et al. 1998; Reagan and Weitzman 1982), the nature of government intervention in agricultural commodity markets (Gardner 1975; Kinnucan and Forker 1987), asymmetric information among the firms (Bailey and Brorsen 1989), the market power (Zachariasse and Bunte 2003; Wann and Sexton 1992; Gohin and Guyomard 2000; von Cramon-Taubadel 1998 and others), the interaction between market power and economy of scale
(McCorriston et al. 2001; Lloyd et al. 2006), intertemporal optimizing behavior of firms (Azzam 1999), the form or retail demand and farm input supply (Weldegebriel 2004), the share of commodity costs in the cost of final product (Bettendorf and Verboven 2000) and other reasons.

Majority of empirical studies confirm asymmetry in food price transmission. Von Cramon-Taubadel (1998) investigated pork prices in Germany and found that the wholesale prices reacted more rapidly to positive shocks than to negative shocks originating at the farm level. Abdulai (2002) showed that increases in producer prices of pork in Switzerland are passed on to retail prices faster than reductions in producer prices. Vavra and Goodwin (2005) studied retail, wholesale and farm level prices of the U.S. beef, chicken and egg markets. Their results indicate significant asymmetries both in terms of speed and magnitude of the adjustment.

On the other hand, Serra and Goodwin (2003) found that asymmetries were not present in the price transmission of highly perishable dairy products in Spain.

Price transmission is closely related to the literature on determination of producer-retail marketing margins. Marketing margin is a difference between the price paid by consumers and that obtained by producers or alternatively marketing margins represent the value of services added to the basic agricultural commodity (Tomek and Robinson 2003). These services include packaging, labelling, processing, transport, information et cetera. The growing size of marketing margins is the source of many political disputes and often results in policy actions aiming at reducing them. 
Despite huge economic and political interest in agricultural price transmission in Europe and elsewhere, there has not been any study on the subject conducted in Slovakia. Our paper is the first to evaluate price transmission along the potato supply chain in Slovakia and it is among the first attempts also to shed some light on the economics of determination of food margins at the Slovak potato market.

Potatoes are a key commodity for both producers and consumers in Slovakia. Producer prices of potatoes have a strong seasonal pattern but since 1990 the prices of potatoes are relatively stable. However, production of potatoes has been declining over the last decade. Table 1 provides production and trade data for potatoes in Slovakia. The reason is a reduction of animal production in Slovakia, decline of production of starch and alcohol, increased competition from abroad, entrance of retail chains on the Slovak market, and abolishment of coupled subsidies due to joining the Common Agricultural Policy of the EU (Seifertova et al. 2009; Drabik et al. 2007, Bartova et al. 2004).

There are various distributional channels used in the marketing of potatoes in Slovakia. Some producers sell potatoes directly to final consumers while other producers of potatoes utilize middlemen (wholesale, retail). Potatoes are also sold directly to processors and restaurants. There are currently four producers groups in active in production and distribution of potatoes in Slovakia. Those producers groups have market share of 17 percent. According to survey conducted by Seifertova et al. (2009) 28 percent of consumers buy potatoes from retailers (hyper and supermarkets), 14 percent of consumers obtain potatoes directly from producers while 30 percent of households still produce their own potatoes. Other consumers use a combination of distributional channels to get potatoes.

\section{MATERIAL AND METHODS}

\section{Data Description}

Monthly price data for Slovakia (from 1999 to 2011) are used to estimate the relationship between producer and retail prices of potatoes. Producer prices were obtained from the ATIS ${ }^{1}$ and consumer (retail) prices come from the Statistical Office of the Slovak Republic. ATIS conducts a representative survey among producers of potatoes on area larger than 15 hectares. Weighted average prices are reported. Consumer prices are obtained from the Statistical Office of the Slovak Republic. The Statistical Office of the Slovak Republic reports average weighted prices for the whole territory of Slovakia. A logarithmic transformation of variables is applied, such that results may be interpreted in percentage change terms.

\section{Price development in the Slovak potato market}

Price development in the Slovak potato market follow year by year repeated pattern, starting with rise in potato

\footnotetext{
${ }^{1}$ A division of the Agricultural Payment Agency in Slovakia
}

prices during spring months, with later decrease in demand for potatoes in summer months (loss of demand from school canteens) leading to decrease in potato price (Table 2).

Table 2 Descriptive statistics of potatoes price series

\begin{tabular}{lccccc}
\hline Variable & Obs. & Mean & $\begin{array}{c}\text { Std. } \\
\text { Dev. }\end{array}$ & Min & Max \\
\hline Producer & 180 & 0.223 & 0.076 & 0.091 & 0.391 \\
Consumer & 180 & 0.482 & 0.153 & 0.240 & 0.870 \\
\hline
\end{tabular}

Source: calculated

There were some peculiarities in price development in Slovak potato market during the period 1999 - 2011. The reasons for these deviations are following:

- $\quad$ The first exemption occurred in 1999; short domestic supplies of potatoes during spring months caused rising imports followed by decrease in potato price to 0.22 EUR per kg. The price of potatoes during this period was permanently lower than the price level achieved in previous years (during spring time). Low potato prices remained until august 1999 when consumers began to lay in for winter stocks. In October 1999 the supply of potatoes increased due imports from Hungary and increased competition led to decrease in prices. Low prices remained also during the year 2000, the annual decrease in potato price reached $30.8 \%$ which reflected the surplus in potato market over the whole supply chain.

- Minimum price for potatoes (0.17 EUR/kg) was imposed from September 1, 2011 to March 31, 2012. This price was monthly mounted by 0.1162 EUR/kg. Minimum price was set for production quota of 162 thousand tons. However this quota was only fulfilled on $95 \%$ in 2001/02 and so the production quota set for the next year was lowered by 22 thousand tons.

- In May 2004 Slovakia joined the European Union. The EU accession brought increasing opportunities for agro-food market, but also increasing competition for domestic producers and lower demand for domestic agro-food products. The season 2004/05 was very difficult for potato producers. Since then, Slovakia became opened to the enlarged market and purchase price of potatoes has been adjusting very quickly to price levels in neighbouring countries. Price fall began already couple of months before the SR accession to the EU. After the accession this fall was even more intensive and continued until February 2005. The first week in February 2005, producer price of potatoes reached historical minimum of 0.1 EUR per kg.

- Unlike the two previous years, the price development in 2006 was positive for potato producers. Since January 2006 producer price of potatoes gradually rose and in April 2006 it was by $140.7 \%$ higher than the year before. In addition, the usual decrease in potato price during summer holidays was milder in 2006 than it was before. In December 2006 potato price reached 0.35 EUR/kg 
Table 1 Production and trade data for potatoes in Slovakia

\begin{tabular}{|c|c|c|c|c|c|c|c|c|c|c|c|}
\hline Indicator & unit & $2002 / 03$ & $2003 / 04$ & $2004 / 05$ & $2005 / 06$ & $2006 / 07$ & $2007 / 08$ & 2008/09 & $2009 / 10$ & 2010/11 & $2011 / 12$ \\
\hline Area & ha & 26.1 & 25.7 & 24.2 & 19.1 & 18.4 & 17.8 & 14.3 & 11.6 & 10.9 & 10.4 \\
\hline Production & $1000 \mathrm{t}$ & 484.3 & 392.4 & 382.0 & 301.2 & 263.1 & 287.7 & 245.3 & 216.1 & 125.9 & 217.3 \\
\hline Import & $1000 \mathrm{t}$ & 31.6 & 31.8 & 54.6 & 67.2 & 78.6 & 55.5 & 74.9 & 79.7 & 157.2 & 74.1 \\
\hline Total supply & $1000 \mathrm{t}$ & 515.9 & 424.2 & 436.6 & 368.4 & 341.7 & 343.2 & 320.2 & 295.8 & 283.1 & 291.4 \\
\hline Export & $1000 \mathrm{t}$ & 0.2 & 4.2 & 9.6 & 22.0 & 16.6 & 7.7 & 15.7 & 5.2 & 1.1 & 3.3 \\
\hline
\end{tabular}

Source: RIAFE yearly reports

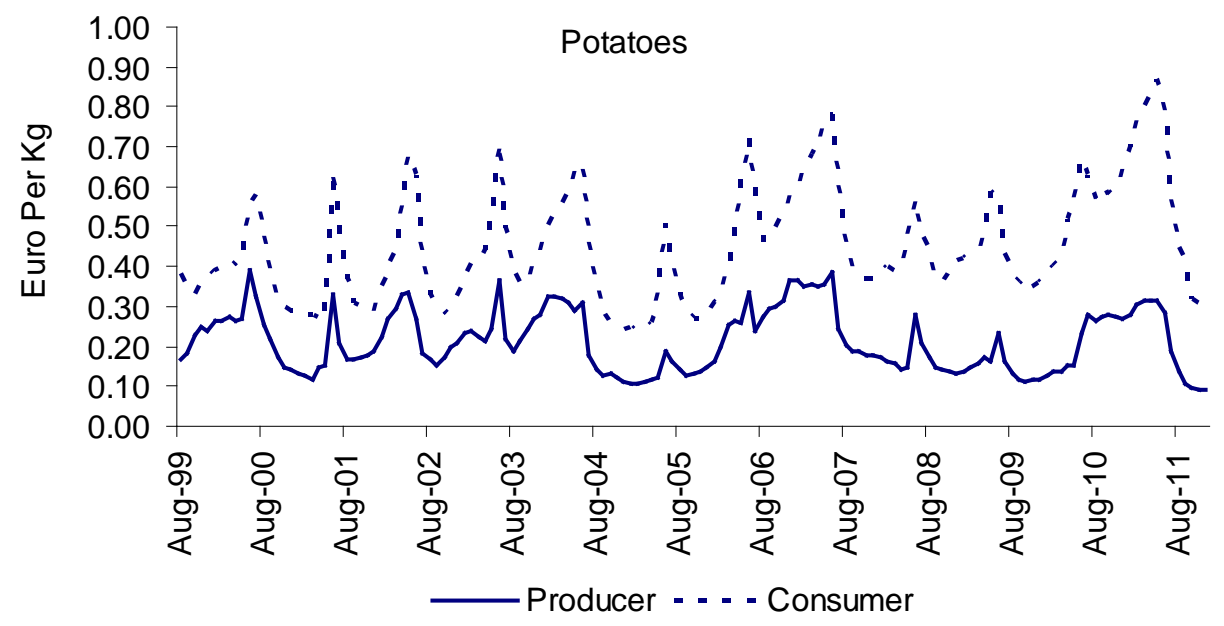

Figure 1 Development of producer and consumer price of potatoes (in EUR per kg). Source: ATIS and Slovak Statistical Office database

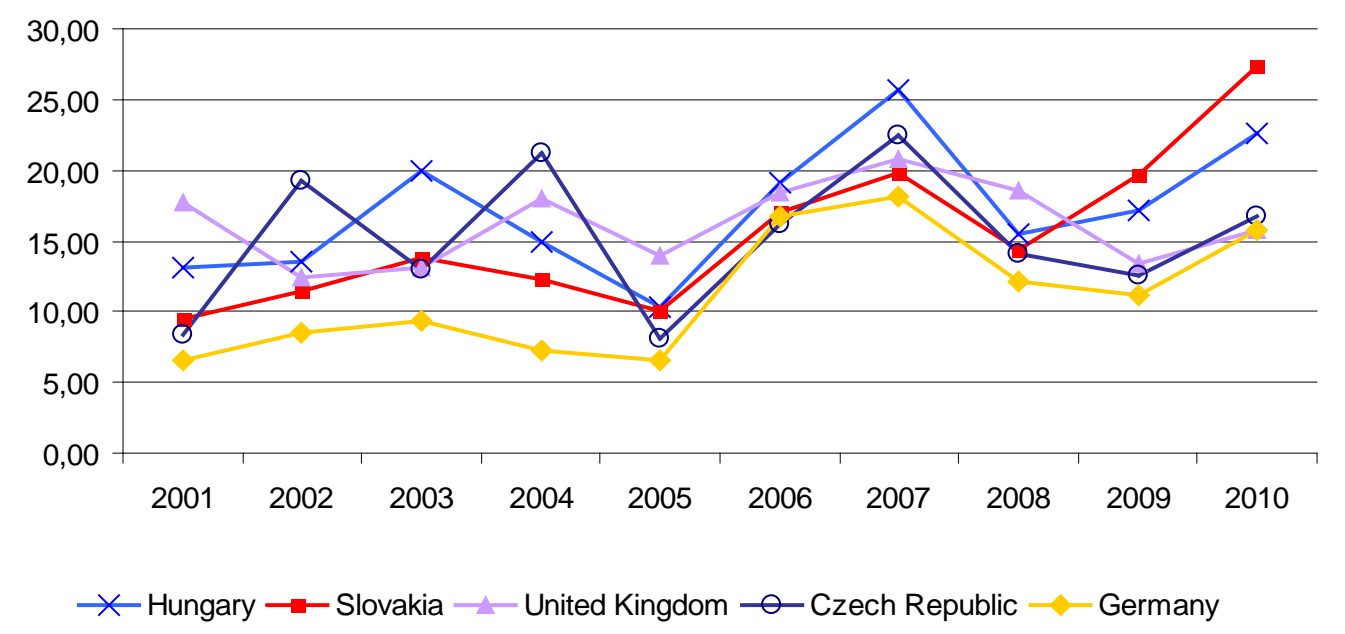

Figure 1 Price development in domestic and foreign potato markets (in EUR / $100 \mathrm{~kg}$ ) Source: EUROSTAT database

(by $134.8 \%$ higher compared to the previous year). Usual "August decrease" in potato prices was extremely sharp this year and the price fell to 0.19 EUR/kg in September 2007 (lower by $31.2 \%$ compared to September 2006).

- Sufficient rainfall in 2008 helped to high production yields and surpluses in potato market which led again to price decrease. Processor and consumer prices of domestic production of potatoes were affected by the same factors as producer prices and their evolution during the period was similar. However their price dynamics was several times faster causing repeating extreme values of processor and retail price spreads. Overall we observe a declining trend in the value of what farmers of potatoes get and increasing value of what processors get. Lagged movement of processor and consumer prices is causing extremely low or extremely high value however they have short duration. 


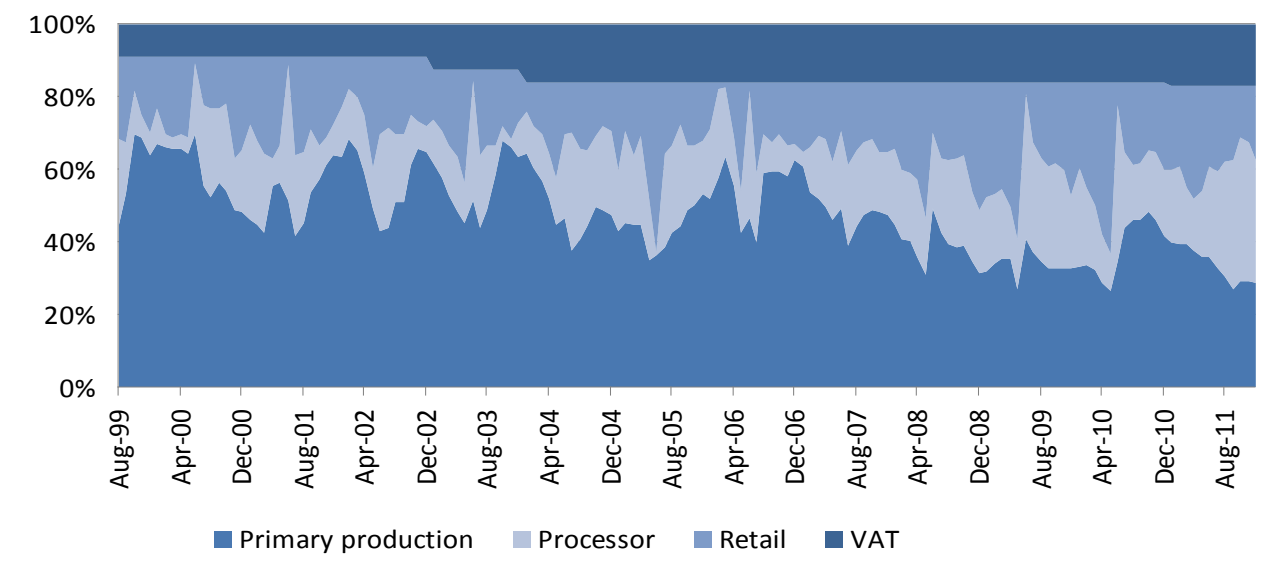

Figure 3 Structure of consumer price of potatoes Source: calculated

\section{Estimation Approach}

We apply time-series modelling techniques to evaluate vertical price transmission from producer to consumer prices and vice versa. In this study, linear cointegration, cointegration with structural breaks in the series, and an asymmetric error correction model are employed to quantify an extent, speed and nature of price adjustment within the potato supply chain in Slovakia. The aim of using different approaches was to compare them and choose the best-fitting error correction model.

As the first step, we test the stationarity of time series using two unit root tests: the augmented DickeyFuller (ADF) test and the Phillips-Perron (PP) test. The number of lags of a dependent variable is determined by the Akaike Information Criterion (AIC). If both time series are not stationary, they are suitable to test for cointegration relationship between them. We employ the Johansen approach to test for cointegration.

The Johansen approach starts with a vector autoregressive model and reformulates it into a vector error correction model:

$$
\begin{aligned}
& Z_{t}=A_{1} Z_{t-1}+\ldots+A_{k} Z_{t-k}+\varepsilon_{t} \\
& \Delta Z_{t}=\sum_{i=1}^{k-1} \Gamma_{i} \Delta Z_{t-i}+\Pi Z_{t-k}+\varepsilon_{t}
\end{aligned}
$$

where $Z_{t}$ is a vector of non-stationary variables (producer and consumer prices), $A$ are different matrices of parameters, $t$ is time subscript, $k$ is the number of lags and $\varepsilon_{t}$ is the error term assumed to follow i.i.d. process with a zero mean and normally distributed $N(0, \sigma 2)$ error structure. The estimates of $\Gamma_{i}$ measure the short-run adjustment to changes in the endogenous variables, while $\Pi$ contains information on the long-run cointegrating relationships between variables in the model.

However, Meyer and von Cramon-Taubadel (2004) noted that the results of tests for price transmission must be interpreted with great caution if there is reason to suspect that there are structural breaks in the price series being investigated. Particularly in transition economies, like Slovakia and other Central and Eastern European countries, there were a lot of changes (economic reforms, significant foreign direct investments in retail sector, EU integration, adoption of CAP, adoption of euro...) that could cause structural break in time series data. From this reason we used a Gregory Hansen test (1996) that allows for the presence of a onetime endogenously determined structural break in the cointegrating vector. A cointegration procedure, which allowed for structural breaks, was used by Bakucs, Falkowski and Ferto (2012) and others.

We consider four Gregory - Hansen types of models (standard cointegration, cointegration with level shift, cointegration with level shift and trend, and cointegration with regime shift).

Model 1: Standard Cointegration

$Y_{t}=\gamma_{1}+\beta_{1} X_{t}+\varepsilon_{t}$

Model 2: Cointegration with Level Shift

$Y_{t}=\gamma_{1}+\gamma_{2} \varphi_{t k}+\beta_{1} X_{t}+\varepsilon_{t}$

Model 3: Cointegration with Level Shift and Trend

$Y_{t}=\gamma_{1}+\gamma_{2} \varphi_{t k}+\phi_{1 t}+\beta_{1} X_{t}+\varepsilon_{t}$

Model 4: Cointegration with Regime Shift

$Y_{t}=\gamma_{1}+\gamma_{2} \varphi_{t k}+\beta_{1} X_{t}+\beta_{2} X_{t} \varphi_{t k}+\varepsilon_{t}$

where $Y$ is the dependent variable, $X$ is the independent variable, $t$ is time subscript, $\varepsilon_{t}$ is the error and $k$ is the break date, $\varphi$ is a dummy variable $(0$ for $t \leq k$ and 1 for $t>k)$.

The above cointegration tests assume symmetric price transmission. In order to capture asymmetric movements in the residuals, Enders and Granger (1998) and Enders and Siklos (2001) propose to use threshold cointegration approach. Assuming the long run relationship between two non-stationary variables $X$ and $Y$ :

$Y_{t}=\lambda_{0}+\lambda_{1} X_{t}+\mu_{t}$

where $\mu$ is the error term. Engle and Granger (1987) show, that cointegration exists if the null hypothesis $\rho=0$ is rejected in:

$\Delta \mu_{t}=\rho \mu_{t-1}+\xi_{t}$

where $\xi$ is the error term for the residuals. Adjustment of 
the series of residuals expressed in $\rho \mu_{t-1}$ would be symmetric. To capture the asymmetry in adjustment process, a two-regime threshold cointegration approach should be used:

$$
\Delta \mu_{t}=I_{t} \rho_{1} \mu_{t-1}+\left(1-I_{t}\right) \rho_{2} \mu_{t-1}+\xi_{t}
$$

where $I_{t}$ is the Heaviside indicator $I_{t}=1$ if $\mu_{t-1} \geq \tau$ or $I_{t}=0$ if $\mu_{t-1}<\tau$. If $\mu_{t-1}$ is bigger than the threshold $\tau$, then adjustment is at the rate $\rho_{1}$. If $\mu_{t-1}$ is smaller than the threshold $\tau$, adjustment is shown in $\rho_{2}$. When $\rho_{1}=\rho_{2}$, then the adjustment process is symmetric. If the null hypothesis $\rho_{1}=\rho_{2}=0$ is rejected, then $X$ and $Y$ are cointegrated and the following threshold autoregressive model (TAR) is estimated:

$$
\begin{aligned}
& \Delta Y_{t}=\theta_{Y}+\delta_{Y}^{+} E_{t-1}^{+}+\delta_{Y}^{-} E_{t-1}^{-}+ \\
& +\sum_{j=1}^{J} \alpha_{Y j}^{+} \Delta Y_{t-j}^{+}+\sum_{j=1}^{J} \alpha_{Y j}^{-} \Delta Y_{t-j}^{-}+ \\
& +\sum_{j=1}^{J} \beta_{Y j}^{+} \Delta X_{t-j}^{+}+\sum_{j=1}^{J} \beta_{Y j}^{-} \Delta X_{t-j}^{-}+v_{Y t}
\end{aligned}
$$

where $\Delta Y_{t}$ and $\Delta X_{t}$ are dependent and independent variables in their first differences, $E$ is the error correction term, $\delta$ represents the speed of adjustment coefficients of $\Delta Y_{t}$ if $Y_{t-1}$ is above and below its long-run equilibrium, $\theta, \delta, \alpha$ and $\beta$ are coefficients and $v$ is the error term, $t$ is time subscript and $j$ is the number of lags. Two error correction terms are defined as:

$$
\begin{aligned}
& E_{t-1}^{+}=I_{t} \mu_{t-1} \\
& E_{t-1}^{-}=\left(1-I_{t}\right) \mu_{t-1}
\end{aligned}
$$

Enders and Granger (1998) and Enders and Siklos (2001) proposed also a model for cointegration, known as momentum threshold autoregressive model (MTAR). The term "momentum" describes the rate of acceleration of prices and takes into account steep variations in the residuals; it is especially valuable when the adjustment is believed to exhibit more momentum in one direction than the other. Heaviside Indicator in this case is $I_{t}=1$ if $\Delta \mu_{t-1} \geq \tau$ or $I_{t}=0$ if $\Delta \mu_{t-1}<\tau$.

Threshold error correction models were used for example by Goodwin and Holt (1999); Goodwin and Harper (2000); Goodwin and Piggott (2001); Abdulai (2002); Serra and Goodwin (2003); Gonzales et al. (2003); Vavra and Goodwin (2005); Liao and Sun (2011) or Ning and Sun (2012). Abdulai (2000, 2002) used both TAR and MTAR models and found out, that the MTAR models fit data better than the others.

To summarize, four asymmetric models are considered in our study. They are threshold autoregression model with threshold value equal to zero (TAR); threshold autoregression model with threshold value estimated (consistent threshold autoregression model - cTAR); momentum threshold autoregression model with threshold value equal to zero (MTAR); and consistent momentum threshold autoregression model with threshold value estimated (cMTAR). A model with the lowest AIC and BIC will be used ${ }^{2}$.

\footnotetext{
2 The econometric estimation was conducted in Stata, R and Matlab. The codes are available upon request from the authors.
}

\section{RESULTS AND DISCUSSION}

\section{Cointegration results}

Non-stationary time series can lead to statistically significant results due to purely spurious correlation. We therefore tested for the stationarity of the price series using augmented Dickey Fuller (ADF) and Phillips Perron (PP) tests. The Augmented Dickey-Fuller and Phillips-Perron tests confirmed that all our time series are non-stationary; we stationarized them by taking first differences. The tests indicated that all variables were stationary in first differences. The lags of the dependent variable in the tests were determined by Akaike Information Criterion (AIC). The stationarity tests showed that the original time series are non-stationary and could be used for cointegration analysis.

Johansen cointegration test results (Table 3) indicate that there is no cointegration relationship between producer and consumer prices of potatoes. Johansen test does not reject the null hypothesis of nocointegration.

Table 3 Johansen cointegration test results

\begin{tabular}{lcccc}
\hline Variables & Rank & $\begin{array}{c}5 \% \\
\text { critical }\end{array}$ & $\begin{array}{c}1 \% \\
\text { critical }\end{array}$ & $\begin{array}{c}\text { Johansen } \\
\text { trace } \\
\text { statistics }\end{array}$ \\
\hline Potatoes & 0 & 25.32 & 30.45 & 21.8600 \\
& 1 & 12.25 & 16.26 & 2.5623 \\
\hline
\end{tabular}

Source: calculated.

However, when we allow for the existence of structural break (Gregory - Hansen procedure) we find cointegration relationship with structural break. The estimated structural break date is March - July 2008. These structural breaks are related to the impact of turbulence on the global commodity markets and food commodity price peak in 2008.

\section{Threshold cointegration}

Threshold cointegration models allow for non-linear relationship between producer and consumer prices and vice versa. The theory does not guide us in the exact model specification and therefore in this paper we used four different threshold models: threshold autoregression model, consistent threshold autoregression model, momentum threshold autoregression model, and consistent momentum threshold autoregression model. We report the results for models with the lowest AIC and BIC.

Threshold cointegration tests lead to the same results as Gregory - Hansen test. Estimated models show, that the prices are cointegrated with threshold adjustment (Table 4). From the tests it follows that there is strong evidence of negative asymmetry for producer price of potatoes. This means that in the case of potatoes retailers react faster to the shocks that stretch the margin than to shocks that squeeze the margin. In other words, consumer prices of potatoes react more fully or rapidly to a decrease in producer prices than to an increase in producer prices. 
Table 4 Gregory - Hansen cointegration test results

\begin{tabular}{ccc}
\hline Model & $\begin{array}{c}\text { Gregory - Hansen } \\
\mathrm{ADF}(\tau) \text { statistics }\end{array}$ & Break date \\
\hline 1 & $-5.60^{* * *}$ & Mar 2008 \\
2 & $-5.80^{* * *}$ & Mar 2008 \\
3 & $-5.54^{* * *}$ & Mar 2008 \\
4 & $-6.27^{* * *}$ & Jul 2008 \\
\hline \\
otes: calculated, *,**,*** denote significance at the 1\%, 5\% and 10\% \\
significance levels.
\end{tabular}

The point estimate for the price adjustment is -0.368 for positive shocks and -0.060 for negative shocks (Table 5). Positive deviations from the long-run equilibrium are eliminated at $36.8 \%$ per month, while the negative deviations from the long-run equilibrium are eliminated at a rate of $6.0 \%$ per month. The point estimates of the coefficients for the error correction terms are -0.201 for positive error correction term and -0.184 for the negative one. Both estimates have correct sign and are significant at $1 \%$ significance level. The magnitude suggests that in the short term consumer price of potatoes respond to the positive deviations by $20.1 \%$ in a month and by $18.4 \%$ to negative deviations.

Because there is strong evidence of cointegration relationship between producer and consumer prices for potatoes we have estimated error correction model and tested for several hypotheses.

Table 6 provides the results of hypotheses tested based on the ECM estimation. According to price determination theory, producer prices determine consumer (retail) prices; that is price transmission flows downward along the supply chain and the direction of causality runs from upstream to downstream sectors. However, the empirical results of studies applied to different commodities in different countries regarding this issue are ambiguous with respect to the direction of causality along the food supply chain (Saghaian 2007). Our results show that the change of producer price affects consumer prices for potatoes. This link is one side only and consumer prices do not Granger cause producer prices of potatoes.

\section{CONCLUSION}

This paper analyzed vertical price transmission along food supply chain for potatoes in Slovakia. Johansen test results revealed that the price series are not cointegrated, which mean there is no long run relationship between producer and consumer prices of potatoes. However this relationship may be deterred by the existence of structural break. Therefore, Gregory - Hansen procedure was used to estimate structural break in the data time series. Structural break in the data occurred due to the turbulence on the global commodity markets in 2008 . Later on we found strong evidence of asymmetry in price transmission for potatoes and tested the causality between producer and consumer prices. For potatoes consumer prices react more rapidly to a decrease in producer prices than to an increase in producer prices. This means that retailers react faster to the shocks that stretch the margin than to shocks that squeeze the margin. There are various explanations behind this. First, significant amount of potatoes are either produced by households themselves or directly obtained from producers which limits the power of middlemen which have to react strongly to price decline at the producer level. Furthermore, potatoes have short shelf life and not reacting to price declines at producer level would create costs for retailers.

Prices at food supply chain are determined at the producer level and transmitted to retail (consumer) level, no causality was observed the other way around.

We found no evidence of a market failure and do not recommend a specific policy recommendation for dealing with issues of vertical coordination. We only recommend policies aiming to improve the competitiveness of the potatoes producers.

Acknowledgments: Authors acknowledge financial support from their projects: Transfop Grant Agreement No. KBBE-265601-4, APVV-0894-11, VEGA1/0682/12 and VEGA1/0830/13. This work was co-funded by European Community under project no 26220220180: Building Research Centre „AgroBioTech".

Table 5 Threshold cointegration test results

\begin{tabular}{|c|c|c|c|c|}
\hline Model & TAR & cTAR & MTAR & cMTAR \\
\hline Threshold & 0.000 & 0.050 & 0.000 & 0.050 \\
\hline Lags & 1 & 1 & 1 & 1 \\
\hline AIC & -359.061 & -360.069 & -361.740 & -376.333 \\
\hline BIC & -346.334 & -347.342 & -349.012 & -363.606 \\
\hline$\Phi(\mathrm{H} 0: \rho 1=\rho 2=0)$ & $7.875 * * *$ & $8.417 * * *$ & $9.321 * * *$ & $17.594^{* * *}$ \\
\hline $\mathrm{F}(\mathrm{H} 0: \rho 1=\rho 2)$ & 0.080 & 1.074 & $2.734 *$ & $17.920 * * *$ \\
\hline$\rho_{1}$ & $-0.145^{* * *}$ & $-0.181^{* * *}$ & $-0.185 * * *$ & $-0.368 * * *$ \\
\hline$\rho_{2}$ & $-0.126 * * *$ & $-0.11 * * *$ & -0.076 & -0.060 \\
\hline$\delta^{+}$ & - & - & - & $-0.201 * * *$ \\
\hline$\delta$ & - & - & - & $-0.184 * * *$ \\
\hline
\end{tabular}


Table 6 Causality and cumulative asymmetry hypotheses

\begin{tabular}{lccccc}
\hline & $H_{01}$ & $H_{02}$ & $H_{03}$ & $H_{04}$ & $H_{05}$ \\
\hline Producer & $14.497^{* * *}$ & $13.925^{* * *}$ & 1.297 & 1.113 & $26.275^{* * *}$ \\
Consumer & 0.804 & $15.753^{* * *}$ & $6.617^{* * *}$ & 0.022 & $28.439^{* * *}$ \\
\hline
\end{tabular}

Notes: ***,*** denote null hypothesis with significance at the $1 \%, 5 \%$ and $10 \%$ significance levels.

H01: Equilibrium adjustment path asymmetry $\left(X . E C T_{t-1}\right.$ pos $=X . E C T_{t-1}$ neg)

H02: Granger causality test (Producer price (y) does not Granger cause...)

H03: Granger causality test (Consumer price $(x)$ does not Granger cause...)

H04: Cumulative asymmetry (Cumulative positive Consumer price = Cumulative negative Consumer price)

H05: Cumulative asymmetry (Cumulative positive Producer price $=$ Cumulative negative Producer price)

\section{REFERENCES}

ABDULAI, A. (2000). Spatial price transmission and asymmetry in the Ghanaian maize market. Journal of Development Economics, 63: 327-349. DOI: $10.1016 /$ S0304-3878(00)00115-2

ABDULAI, A. (2002). Using threshold cointegration to estimate asymmetric price transmission in the Swiss pork market. Applied Economics, 34 (6): 679-87. http://dx.doi.org/10.1080/00036840110054035

AZZAM, A.M. (1999). Asymmetry and Rigidity in Farm-Retail Price Transmission. American Journal of Agricultural Economics, Vol. 81, pp. 525-533. http://dx.doi.org/10.2307/1244012

BAILEY, D. \& BRORSEN, B.W. (1989). Price Asymmetry in Spatial Fed Cattle Markets. Western Journal of Agricultural Economics, Vol. 14(2), pp. 246252

BAKUCS, L.Z., FALKOWSKI, J., FERTO, I. (2012). Price transmission in the milk sectors of Poland and Hungary, Post-Communist Economies, 24:3, 419-432. http://dx.doi.org/10.1080/14631377.2012.705474

BALKE, N.S., BROWN, S.P.A. and M.K. YÜCEL, (1998). Crude Oil and Gasoline Prices: An asymmetric Relationship? Federal Reserve Bank of Dallas, Economic Review, 2-11.

BALL, L. \& MANKIW, N.G. (1994). Asymmetric Price Adjustment and Economic Fluctuations. Economic Journal 104: 247-261. http://dx.doi.org/10.2307/2234746 BARTOVA, L., POKRIVCAK, J., CIAIAN, P. (2004). Slovenský Gold model a trh so zemiakmi v SR. In: Kvantitatívne metódy v ekonómii : zborník vedeckých prác, Nitra, december 2004. Slovenská štatistická a demografická spoločnost', 2004. ISBN 80-88946-40-9. s. 7-11.

BETTENDORF, L., VERBOVEN, F. (2000). Incomplete transmission of coffee bean prices in the Netherlands. European Review of Agricultural Economics, 27, 1-16. http://dx.doi.org/10.1093/erae/27.1.1

BUNTE, F. (2006). Pricing and Performance in AgriFood Supply Chains. In: C.J.M. Ondersteijn, J.H.M. Wijnands, R.B.M. Huirne and O. van Kooten (eds.), Quantifying the agri-food supply chain, 37-45., 2006 Springer.

DRABIK, D., POKRIVCAK, J., CIAIAN, P. (2007).

Trade creation and diversion in the enlarged EU market: evidence for agricultural trade in Slovakia. Finance $a$ úvěr. ISSN 0015-1920. 57/ 9-10 (2007), p. 433-447.

ENDERS W. and GRANGER C.W.J. (1998). Unit-root tests and asymmetric adjustment with an example using the term structure of interest rates. Journal of Business and Economic Statistics, 16, pp. 304-311. http://dx.doi.org/10.2307/1392506

ENDERS, W. and SIKLOS, P. L. (2001). Cointegration and threshold adjustment, Journal of Business and
Economic
Statistics,
19
(2):166-177. http://dx.doi.org/10.1198/073500101316970395

ENGLE, R. F., GRANGER, C. W. J., (1987). Cointegration and error correction: representation, estimation, and testing. Econometrica, 55(2): 251-276. http://dx.doi.org/10.2307/1913236

GARDNER, B.L. (1975). The Farm-Retail Price Spread in a Competitive Food Industry. American Journal of Agricultural Economics 57, 383-406. http://dx.doi.org/10.2307/1238402

GOHIN, A. and GUYOMARD, H. (2000). Measuring market power for food retail activities: French evidence. Journal of Agricultural Economics, 51, 181-195. http://dx.doi.org/10.1111/j.1477-9552.2000.tb01222.x

GONZALES F., GUILLOTREAU P., LeGREL L., and SIMIONI M. (2003). Asymmetry of price transmission within the French value chain of seafood products. INRA Working Paper.

http://netec.mcc.ac.uk/WoPEc/data/Papers/reainrawp49.h $\underline{\mathrm{tml}}$

GOODWIN, B. K., HOLT, M. T. (1999). Asymmetric adjustment and price transmission in the US beef sector. Amer. J. Agr. Econ. 81, 630-637.

GOODWIN, B. K., and HARPER, D. C. (2000). Price transmission, threshold behaviour, and symmetric adjustment in the U.S. pork sector. Journal of Agricultural and Applied Economics 32 (3): 543-553.

GOODWIN, B. K. and PIGGOT, N. (2001). Spatial market integration in the presence of threshold effects, American Journal of Agricultural Economics, 83: 302317. http://dx.doi.org/10.1111/0002-9092.00157

GREGORY, A. \& HANSEN, B. (1996). Residual-based tests for cointegration in models with regime shifts. Journal of Econometrics, 70, 99-126. http://dx.doi.org/10.1016/0304-4076(69)41685-7

LIAO, X. and C. SUN (2011). Asymmetric price transmission in the wood products sector in the Southern United States. Pages 14-31 in Proceedings of the 2010 Southern Forest Economics Workers Annual Meeting.

LLOYD, T., McCORRISTON, S., MORGAN, W., RAYNER, T. (2006). Food Scares, Market Power and Price Transmission: the UK BSE Crisis.

McCORRISTON, S., MORGAN, C.W. and RAYNER, A.J. (2001). Price transmission and the interaction between market power and returns to scale. European Review of Agricultural Economics, 28: 143-160. 
MEYER, J. \& von CRAMON-TAUBADEL, S. (2004). Asymmetric Price Transmission: A Survey. Journal of Agricultural Economics 55: 581-611. http://dx.doi.org/10.1111/j.1477-9552.2004.tb00116.x NING, Z. \& C. SUN (2012). Vertical price linkage between timber and forest products prices in the South. In S.R. Mehmood, editor, Proceedings of the 2011 Southern Forest Economics Workers (SOFEW) Annual Meeting, Little Rock, AR. 15 pp.

PELTZMAN, S. (2000). Prices Rise Faster than They Fall. Journal of Political Economy. 108: 466-502. http://dx.doi.org/10.1086/262126

REAGAN, P. and WEITZMAN, M. (1982). Asymmetries in price and quantity adjustments by the competitive firm. Journal of Economic Theory, 27, 410420. http://dx.doi.org/10.1016/0022-0531(82)90037-0

RIAFE: Situačné a výhl'adové správy. Available at: http://www.vuepp.sk/04_komodity.htm

SAGHAIAN, S.H. (2007). Beef safety shocks and dynamics of vertical price adjustment: the case of BSE discovery in the U.S. beef sector. Agribusiness 23(3): 333-348. http://dx.doi.org/10.1002/agr.20127

SEIFERTOVÁ, A. (2009). Marketingová vertikála zemiakov a zemiakových výrobkov na Slovensku a väzba na európske trhy. SPU v Nitre, 1 vydanie, 70 s., ISBN 978-80-552-0269-3

SERRA, T. and GOODWIN, B.K. (2003). Price transmission and asymmetric adjustment in the Spanish dairy sector. Applied Economics, 2003, 35, 1889-1899. http://dx.doi.org/10.1080/00036840310001628774

TOMEK, W.G. and ROBINSON, K. (2003). Agricultural Product Prices. Cornell University Press, Ithaca and London.

VAVRA, P. \& GOODWIN, B.K (2005). Analysis of Price Transmission Along the Food Chain. OECD Food, Agriculture and Fisheries Working Papers, No. 3, OECD Publishing. http://dx.doi.org/10.1787/752335872456 von CRAMON-TAUBADEL, S. (1998). Estimating asymmetric price transmission with the error correction representation: An application to the German pork market, European Review of Agricultural Economics, Vol. 25, pp. 1-18. http://dx.doi.org/10.1093/erae/25.1.1

WANN, J.J. and SEXTON. R.J. (1992). Imperfect competition in multi-product food industries with an application to pear processing. American Journal of Agricultural Economics, 72, 980-990.

WELDEGEBRIEL, H.T. (2004). Imperfect Price Transmission: Is Market Power Really to Blame? Journal of Agricultural Economics 55: 101-114. http://dx.doi.org/10.1111/j.1477-9552.2004.tb00082.x

ZACHARIASSE, V. and F. BUNTE (2003). How are farmers faring in the changing balance of power along the food supply chain? OECD Conference: Changing Dimensions in the Food Economy: Exploring the Policy Issues, The Hague, 6-7 February, 2003. 